\title{
Characteristics and distribution of terpenes in South Korean forests
}

\author{
Jaeseok Lee ${ }^{1,2}$, Kyoung Sang Cho ${ }^{1,2}$, Youngjae Jeon'1, Ji Beom Kim', Young-ran Lim', Kyungho Lee ${ }^{1,2}$ \\ and Im-Soon Lee $\mathrm{e}^{1,2^{*}}$
}

\begin{abstract}
The importance of forests continues to increase throughout the world, and one of the reasons is that a forest is a major place to emit terpenes, which have been reported to be beneficial to human health. In South Korea, forests occupy about $64 \%$ of the total land area and consist mainly of pine and oak trees. Since only a limited number of forests have been analyzed to date, a comprehensive understanding of terpenes emitted from regional forests remains in its infancy in Korea. Here, to gain insights into terpenes from regional forests located in South Korea, we review the characteristics of Korean forests and recent studies on major terpenes emitted from regional forests as well as from native trees dominant in South Korea. We also discuss meteorological factors that affect the terpene emissions in Korean forests. In conclusion, 18 types of terpenes were detected in Korean forests and their compositions in different forests are largely dependent on the dominant plant species in the forest. Moreover, terpene emissions in Korean forests are affected by various environmental factors, including temperature, amount and duration of daylight, season, and age of trees. To improve the understanding of the characteristics of terpene distribution, more studies are required on the terpene production of Korean forests in various regions.
\end{abstract}

Keywords: Coniferous tree, South Korean forest, Terpene, Terpene composition

\section{Background}

Terpenes constitute a large and diverse class of aromatic organic compounds (Gershenzon and Dudareva 2007, Zulak and Bohlmann 2010). Many terpenes have a unique odor and may protect the plants from herbivores (Martin et al. 2003, Pichersky et al. 2006). The basic structural chemistry of terpenes is the linkage of isoprene units $\left(\mathrm{C}_{5} \mathrm{H}_{8}\right)$ such as dimethylallyl pyrophosphate and isopentenyl pyrophosphate (Lange and Ahkami 2013, Mewalal et al. 2017). These two common C5 building blocks generate various terpenes by head-to-tail condensation (Dubey et al. 2003). Depending on the number of linked isoprene units, the resulting terpenes are classified into mono-, sesqui-, di-, sester-, tri-, sesquar-, tetra-, and polyterpenes $\left(C_{10}, C_{15}, C_{20}, C_{25}, C_{30}, C_{35}, C_{40}\right.$, and long chains of many $C_{5}$, respectively) (Kirby and Keasling 2009).

\footnotetext{
* Correspondence: islee@konkuk.ac.kr

${ }^{1}$ Department of Biological Sciences, Konkuk University, Seoul 05029, South Korea

${ }^{2}$ Research Center of Coupled Human and Natural Systems for Ecowelfare, Konkuk University, Seoul 05029, South Korea
}

Forest plants are a major source of a broad range of biogenic volatile organic compounds (BVOCs) including terpenes. Although isoprenes and oxygenated compounds are of importance among the BVOCs in addition to terpenes, monoterpenes and isoprenes are the major compounds that contribute to substantial emission levels to the atmosphere (Guenther 2006, Peñuelas and Staudt 2010, Pokorska et al. 2012, Aydin et al. 2014). It has been reported that monoterpenes are mostly emitted by coniferous species while broad-leaved trees mainly emit isoprenes (Zimmerman 1979, Warneck 1988, Bao et al. 2008).

The composition of BVOCs is dependent on the dominant plant species in the forest. Thus, regional estimates of BVOC emissions reported in the literature are frequently based on an inventory of the main plant species (Tollsten and Müller 1996). Currently, such inventories are often used as input conditions for models in combination with various meteorological parameters to estimate emission rates (Sindelarova et al. 2014). Thus, for a better understanding of regional BVOC emissions, researches on the distribution of terpenes and 
their emission rates from regional forests have been carried out in many countries. In the case of Africa, investigations on BVOC emissions were conducted at southern African savannas in the Republic of South Africa (Guenther et al. 1996), and grassland savannas and primary rainforest areas in central Africa (Klinger et al. 1998). In Europe, monoterpene emissions were investigated in Swedish as well as Finnish boreal forests (Janson 1993, Hakola et al. 2000, Hakola et al. 2003). Several studies have also been conducted in the Americas: BVOCs emissions were analyzed in the forests around Mexico City (Dominguez-Taylor et al. 2007), a lowland tropical wet forest in Costa Rica (Geron et al. 2002), a station at Balbina of Amazonia in Brazil (Kesselmeier et al. 2000), and the USA (Geron et al. 2000, Kim 2001). In Asia, Klinger et al. (2002) estimate VOC emissions throughout China using forest and emission inventory data acquired from seven different regions of China. In addition, Bao et al. (2008) mapped areas with potential BVOC emissions at the Kinki region in Japan using BVOC emission data from ten major plant species. Overall, these worldwide studies emphasize importance of comprehensive understanding of BVOC emissions because they vary depending on multifaceted factors, such as climate, location, as well as ecological succession.

According to the data of the National Statistical Office in 2015 , about $64 \%$ of the total land area in South Korea is forested with several dominant tree species (Korean Statistical Information 2015). Despite the substantial forested areas, research on atmospheric conditions of forest ecosystems in the Korean peninsula remains in the early stages. In this review, we give an overview of the characteristics of Korean forests, and summarize recent studies that describe major terpene compounds emitted from the native dominant tree species as well as forest areas in South Korea. In addition, various meteorological factors affecting terpene emissions in several typical Korean forests are also discussed.

\section{Characteristics of Korean forests}

Korean forests are classified into three types: coniferous forests, deciduous forests, and mixed forests (Korea Forest Service 2016). The area covered by coniferous forests was $41 \%$ in 2010 and has been on the decline since 2013. They now account for about $37 \%$ of Korean forests according to data reported in 2016 (Korea Forest Service 2016). Conifers in the Pinus are comprised of 126 different tree species, of which six are present in Korean forests (Lee, 1982; The Plant List Version 1.1). The dominant species in these forests are Pinus densiflora (Japanese red pine), $P$. koraiensis (Korean pine), Larix leptolepis (Japanese larch), and Pinus rigida (Pitch pine), all of which are classified as Pinophyta, commonly known as conifers. The most abundant conifer in South Korea is P. densiflora, which is native to Korea, Japan, China, and East Russia ( $\mathrm{Yu}$ et al. 2004) and comprises about $87 \%$ of the species in coniferous forests in South Korea (Korea Forest Service 2016).

In the deciduous forests that occupy $32 \%$ of the country, oak species in the genus Quercus are dominant such as Q. mongolica (Mongolian oak), Q. serrata (Korana oak), and Q. variabilis (Chinese cork oak). Most Quercus forests in South Korea are dominated by Q. mongolica (Yun et al. 2011) in areas of high altitude, whereas other Quercus species, such as $Q$. serrata and $Q$. variabilis, occur in areas of lower altitudes (Lee 2002). Since the $P$. densiflora species flourish at high temperatures and arid environments compared to Q. mongolica., Q. mongolica forests occupy areas of higher altitude in comparison to $P$. densiflora forests. As a result, a distinctive altitudinal distribution pattern of the two forests exists in the central and southern parts of the country. As the latitude increases, the elevation of the borderline between the two forests decreases, and more Q. mongolica forests occur.

Mixed forests, where coniferous and broad-leaved trees coexist, cover $27 \%$ of the forest area. Among them, the most abundant type is a forest where Quercus and Pinus are mixed. Typical species of trees that can be found include P. densiflora, Q. mongolica, Q. serrata, and Q. variabilis.

In the southern coastal and island zone of the country as well as at the low-altitude areas of Jeju Island, evergreen broad-leaved forests are established due to their relatively warm coastal climate (Oh 1994, Kwak et al. 2013). However, the area covered by pine and oak trees increases with increasing altitude, and alpine trees such as Abies koreana, known as Korean fir, specifically appear at the summit altitude region of Mt. Halla (Kong 1999).

\section{Terpenes from dominant tree species in Korean forests}

According to the National Forest Inventory 5 (2006 2010) conducted by the Korea Forest Promotion Institute, the ranking of commercial coniferous tree species in South Korea in terms of occupied areas is $P$. densiflora $\left(2.220 \times 10^{6} \mathrm{ha}\right)$, P. rigida $\left(0.313 \times 10^{6} \mathrm{ha}\right)$, L. leptolepis $\left(0.280 \times 10^{6} \mathrm{ha}\right)$, P. koraiensis $\left(0.235 \times 10^{6}\right.$ ha), Chamaecyparis obtusa $\left(0.024 \times 10^{6}\right.$ ha), and Cryptomeria japonica $\left(0.014 \times 10^{6}\right.$ ha) $($ Kim 2016). It is considered that P. densiflora has become dominant as a pioneer species in the natural forests of South Korea due to large-scale afforestation and rehabilitation of degraded forests in addition to natural succession. Since various monoterpenes have been found in the emissions of BVOCs of coniferous trees (Pier 1995, Kim et al. 2004, Kim et al. 2007a), it is important to analyze the major monoterpenes emitted from these tree species for the characterization of terpene emission in the forests of South Korea. On the other hand, Quercus 
species are broad-leaved trees that emit isoprene as the main BVOC (Pier 1995, Harley et al. 1999, Xiaoshan et al. 2000, Kim et al. 2007b). Thus, although Quercus trees occupy the largest area second to $\left(1.078 \times 10^{6}\right.$ ha) Pinus trees in South Korea (Kim 2016), the effects of terpene emitted from the Quercus species in the forests of South Korea may be relatively less significant.

Despite limited data regarding BVOC emission rates and the composition of emissions for individual tree species in the forests of South Korea, research on monoterpene emissions of $P$. densiflora has been well established compared to other tree species because it is the dominant species of Korean forests in general. Lim et al. (2008) investigated the composition of monoterpenes emitted from $P$. densiflora by using a vegetation enclosure chamber in two natural mountain environments, Mt. Worak and Mt. Gumsung, located in the central and the southern part of South Korea, respectively. Although the major monoterpene compounds sampled from $P$. densiflora were $\alpha$-pinene, myrcene, and $\beta$-phellandrene, the composition ratios of other individual monoterpenes were varied between the two sampling sites depending on the sampling seasons, especially in summer and winter). Interestingly, however, no significant difference in the composition ratios was observed between the monoterpenes emitted from $P$. densiflora at Mt. Gumsung and Mt. Jiri in the summer (Kim et al. 2004). Mt. Gumsung and Mt. Jiri are located at similar latitudes, $35^{\circ} 04^{\prime} \mathrm{N}$ and $35^{\circ}$ $37^{\prime} \mathrm{N}$ respectively, thus, these results indicate that monoterpene emission from $P$. densiflora may be affected by the latitude of the location where the trees have grown in the summer. Despite some variations in monoterpene ratios, other studies also confirmed that three monoterpenes from $P$. densiflora, $\alpha$-pinene, myrcene, and $\beta$-phellandrene are dominantly emitted regardless of location or season in Korea (Kim et al. 2004, Jo and Kim 2010, Son et al. 2012). The dominant emission of the three monoterpenes from $P$. densiflora was also observed in studies conducted overseas: an emission experiment performed with cultured $P$. densiflora in a greenhouse in Japan demonstrated high emission of $\alpha$-pinene, myrcene, and $\beta$-phellandrene (Yokouchi and Ambe 1984).

$P$. rigida occupies the second largest area among commercial coniferous trees in South Korea (Kim 2016). By using a dynamic flow-through vegetation enclosure chamber, Son et al. (2012, 2015) examined monoterpenes from $P$. rigida at two locations, Mt. Gumsung and Mt. Jiri, and showed that the most abundant types were $\alpha$-pinene, $\beta$-pinene, myrcene, and $\alpha$-terpinene in both locations. Despite the similar latitudes, the ratios of the individual components were markedly diverse in the two locations unlike the results found for $P$. densiflora. In addition, the composition ratio of $\beta$-pinene from $P$. rigida seasonally changed and this compound became more dominant than $\alpha$-pinene in the spring. A study performed by Kurose et al. (2007) with $P$. rigida oil also reported that $\alpha$-pinene $(11.1 \%)$ was the second major component, next to $\beta$-pinene (15.2\%). It is noteworthy that the dominant monoterpenes of $P$. rigida are different from those of $P$. densiflora because these results indicate that distinct species may emit significantly diverse terpenes depending on their genetic background albeit belonging to the same genus.

In the samples emitted from cut branches of $P$. koraiensis from Pochun in the Gyeonggi-Province, the major monoterpenes were $\alpha$-pinene, camphene, myrcene, and $d$ limonene except during the fall, when sabinene emission rates dominated (Kim et al. 2005). In a study of field samples at Mt. Worak and Mt. Gumsung, Son et al. (2015) also showed a similar composition of individual terpenes from $P$. koraiensis, but the terpene emission rates of $P$. koraiensis were much lower compared to other conifers. In addition, a study of essential oils extracted from leaves and pinecones of $P$. koraiensis reported that $\alpha$-pinene, camphene, myrcene, and d-limonene were the main extracted components (Xiaoyu et al. 2006, Kurose et al. 2007, Kim and Lee 2015). It is noteworthy that the analysis results of the terpene composition from the essential oils were similar to the emission results from native tree samples.

Deciduous conifers, such as larches, also emit monoterpenes. Kim et al. (2007a) reported that the major monoterpenes emitted by L. leptoleis at Mt. Worak were $\alpha$-pinene, $\alpha$-terpinene, and myrcene. However, the leaf oil extracted from $L$. leptoleis contained $\Delta^{3}$-carene as well as $\alpha$-pinene and myrcene as the major monoterpene components (Holm and Hiltunen 1997). The larch trees exhibited a lower monoterpene emission rate than $P$. densiflora and $P$. rigida, but a higher rate than $P$. koraiensis (Son et al. 2015). This indicates that $P$. densiflora is the top monoterpene emitter among the tested confers since it releases the highest level of terpenes per unit hour into atmosphere.

Abies holophylla in South Korea exhibited composition ratios of terpene emissions in the order of $\Delta^{3}$-carene (43.6\%), $\alpha$-pinene (22.1\%), and camphene (16\%) (Son et al. 2012). Based on the analysis of essential oils extracted from the leaves collected in the central part of South Korea, a variety of useful terpene compounds were present in $A$. koreana such as trans-caryophyllene, $\alpha$ pinene, carene, bornyl acetate, camphene, myrcene, and humulene (Yeon et al. 2015). In contrast, other Abies species had different monoterpene emission rankings; $A$. alba (European silver fir) emitted with a ranking of d-limonene, camphene, and $\alpha$-pinene, while $A$. religiosa (sacred fir) in Mexico exhibited a ranking of $\alpha$-pinene, $\beta$-pinene, and $\Delta^{3}$ carene (Dominguez-Taylor et al. 2007). Similarly to Pinus trees, these reports support that BVOC compositions emitted from species that belong to the genus Abies may vary markedly depending on their genetic background in 
addition to various growth and climatic conditions (Padhy and Varshney 2005).

A. koreana, a representative of coniferous trees in Jeju Island, exhibited a very high emission rate of $\mathrm{d}$-limonene, followed by $\alpha$-pinene, $\beta$-pinene, camphene, and $\beta$ phellandrene as the major species of monoterpenes (Kim and Lee 2010, Kim et al. 2013a). Interestingly, A. koreana showed the highest hourly emission rate while C. obtusa had the lowest rate, among five dominant tree species of conifers in Jeju Island (P. thunbergii, A. koreana, C. japonica, P. densiflora, and C. obtusa) (Kim and Lee 2010).

C. japonica in Jeju Island was found to emit $\alpha$ pinene, sabinene, and $\Delta^{3}$-carene as the major species of monoterpene (Kim and Lee 2010, Kim et al. $2013 \mathrm{~b})$. The emission rate of $\alpha$-pinene and sabinene dominated among those terpenes in addition to a variety of monoterpenes, and the result was confirmed by other research using emission samples from Jangsung in the South Jeolla-Province (Kim et al. 2005).

In the composition of emitted monoterpene species from C. obtusa from Jangsung, the major monoterpenes were $\alpha$-pinene, sabinene, myrcene, $d$-limonene; the same monoterpene compounds were detected in C. japonica except for $\Delta^{3}$-carene (Kim et al. 2005), whereas in the study in the Jeju areas, the main monoterpenes were $\alpha$ pinene, $\beta$-phellandrene, myrcene, and $\Delta^{3}$-carene (Kim and Lee 2010). Despite the lowest emission rate in the study by Kim and Lee (2010), a quantitative analysis of five coniferous trees from South Korean forests showed that the yield of crude oil extracted from C. obtusa leaves was the highest among the conifers, nine to ten times higher than for the other trees (Yeon et al. 2015).

\section{Characteristics of terpene emission in various regional forest regions in Korea}

In addition to studies conducted on monoterpenes from individual tree species in closure chambers described in the previous section, characterization of the compounds collected directly from open fields of various forests have also been performed in Korea (Table 1). Since this type of studies measures terpene emissions from air in situ that we inhale while walking through the forest, data collected from these studies are more meaningful in a practical aspect.

In the northern region of South Korea, terpene emissions in Seoul and Gangwon-Province were analyzed (Kim et al. 2013c, Kim et al. 2014). In a study carried out by the National Institute for Environmental Research of South Korea, five monoterpenes ( $\alpha$-pinene, $\beta$-pinene, $\mathrm{d}$-limonene, camphene, and $\Delta^{3}$-carene) were detected in the Taehwa research forest, which is located $35 \mathrm{~km}$ from the center of the Seoul Metropolitan Area (Kim et al. 2013c). The samples for analyzing the VOCs were collected in the middle of a $P$. koraiensis plantation $(300 \times 300 \mathrm{~m})$, surrounded by a mixed forest. Interestingly, the main terpene type emitted by trees in the same area showed seasonal variation. For example, camphene (86\%) dominated the monoterpene concentrations in May, but $\alpha$-pinene (43\%) was dominant in September (Kim et al. 2013c). Another study detected 13 types of terpenes at a spring originating from the pine tree forest in Daegwallyeong located in the Gangwon-Province (Kim et al. 2014). Unlike the results for the Taewha research forest, $\alpha$-pinene (31\%) was dominant in May, followed by $\mathrm{d}$-limonene (14\%) and $\beta$-pinene (12\%) (Kim et al. 2014), indicating that the composition ratios can be influenced not only by season but also by location.

In the central region of South Korea, terpene production was analyzed in a three-season field study (spring, summer, and fall) at five recreation forests (Mt. Joryung, Mt. Bonghwang, Mt. Minjuji, Mt. Jangryung, and Soseonam) in the North Chungcheong-Province area (Lee et al. 2012b). No significant seasonal differences were found in all the sites in this study. The results averaged for the three seasons showed that at Mt. Joryung, Mt. Jangryung,

Table 1 Dominant species at the sampling sites in the forests

\begin{tabular}{llll}
\hline Location (Province) & Forest & Dominant species & Reference \\
\hline North Chungcheong & Mt. Joryung & Pine tree & Lee et al. 2012b \\
& Mt. Bonghwang & Lee et al. 2012b \\
& Mt. Minjuji & Oak tree & Lee et al. 2012b \\
& Mt. Jangryung & Larch tree & Lee et al. 2012b \\
& Soseonam & Pine tree & Lee et al. 2012b \\
Gangwon & Daegwallyeong & Pine tree & Kim et al. 2014 \\
Gyeonggi & Teahwa & Pine tree & Kim et al. 2013c \\
South Jeolla & Seonam Temple & Pine tree & Oh et al. 2012 \\
& Suncheon Bay & Retinispora tree & Oh et al. 2012 \\
& Juknokwon & Reed & Oh et al. 2012 \\
& Jangheung Woodland & Bamboo & Oh et al. 2012 \\
& Bulgap Temple & Retinispora tree & Oh et al. 2012 \\
\hline
\end{tabular}


Soseonam, and Mt. Bonghwang (areas dominated by pine and oak trees), $\alpha$-pinene $(45 \sim 50 \%)$ was dominant, followed by $\beta$-pinene (20 26\%) and camphene (13 18\%). At Mt. Minjuji, which is dominated by larch trees, sabinene (38\%) was dominant, followed by $\alpha$-pinene (21\%) and camphene (19\%) (Lee et al. 2012b).

In the South Jeolla-Province in the southern region of South Korea, the distribution of monoterpene in the ambient air was investigated in a three-season field study in five forests (Seonam temple, Suncheon bay, Juknokwon, Jangheung Woodland, and Bulgap temple) representing different plant communities (Oh et al. 2012). Interestingly, the dominant terpene compounds varied for different seasons in the different forests, although the major terpene components were similar: $\alpha$-pinene, camphene, sabinene, $\beta$-pinene + myrcene, and d-limonene. $\beta$-pinene + myrcene (36\%) was the highest at Juknokwon, which is dominated by bamboo, and $\alpha$-pinene (31\%) and d-limonene (32\%) were highest at Jangheung Woodland, which is dominated by cypress forest, and at Suncheon bay, dominated by reeds, respectively (Oh et al. 2012). Two studies investigated monoterpene emissions at Mt. Mudeung located in Gwangju (Lee et al. 2012a, Lee, et al. 2015a, b). The authors reported that 11 15 terpenes were found in several different sampling sites in spring and that $\alpha$-pinene was the dominant compound followed by coumarin and sabinene (Lee, et al. 2015a, b).

The distribution of 11 monoterpenes ( $\alpha$-pinene, $\beta$ pinene, camphene, $d$-limonene, sabinene, $\rho$-cymene, $\beta$ phellandrene, myrcene, $\Delta^{3}$-carene, $\alpha$-terpinene, and $\gamma$ terpinene) was analyzed in the Jeolmul and Seogwipo Natural Recreation Forests of Jeju Island (Kim et al. 2013a, 2013b). $\alpha$-Pinene and sabinene were dominant in the walking paths of C. japonica in the Jeolmul Natural Recreation Forest, whereas d-limonene was dominant in areas of $A$. koreana (Kim et al. 2013a). In the cypress forest of the Seogwipo Natural Recreation Forest, the concentration of sabinene was highest, followed by dlimonene and $\alpha$-pinene (Kim et al. 2013b).

Taken together, to date, the monoterpene distributions of 17 Korean forests have been reported in previous studies, and seasonal patterns of terpene emissions of 13 forests are summarized in Fig. 1. In those previous studies, detections of 18 monoterpenes were described in Korean forests, among which $\alpha$-pinene, sabinene, $d$ limonene, $\beta$-pinene, and camphene were common. The concentration ratio of monoterpenes is dependent on the composition of the tree species, which may be responsible for some regional specificity.

\section{Meteorological factors affecting terpene emissions in Korean forests}

The emission rate of BVOCs from plants varies depending on various meteorological factors. In general, temperature and intensity of sunlight are considered two major factors (Lerdau et al. 1995, Monson et al. 1995, Staudt and Seufert 1995), but some researchers have claimed that sunlight is the most important factor (Guenther 1993, Sabillón and Cremades 2001). Temperature is an important factor for coniferous trees, while the intensity of sunlight is more important for broadleaf trees. Korea has four distinct seasons; therefore, temperature, intensity of sunlight, diurnal temperature fluctuation, hours of daylight, and the amount of daylight differ depending on the season. Therefore, the effects of temperature and sunlight intensity on the emission rates and concentration of terpenes in the air are closely related to season and time of day in Korea.

\section{Temperature}

Emission of terpenes is highly temperature dependent as shown in terpene transpiration in pine needles. Emissions of $\alpha$-pinene and $\beta$-pinene increased with higher temperatures in Korean pine trees (Kim 2001). Standard emission rates at $30{ }^{\circ} \mathrm{C}$ at Mt. Gumsung and Mt. Jiri increased with higher temperatures (Guenther et al. 1991). However, tree species as well as growing conditions, including climatic conditions and soil qualities, also appeared to affect the emission rates of VOCs (Kim et al. 2004); it is likely that several complex factors such as season and many other factors are more important with regard to the emission rates of terpenes than a single factor such as temperature (Ji et al. 2002, Kim et al. 2004, Lee et al. 2012a).

\section{The amount of daylight and time of day}

The concentration of terpenes varies depending on the time of day in which many factors such as wind and the amount of daylight are in diverse conditions (Monson et al. 1995, Staudt and Seufert, 1995). For example, the concentration of monoterpenes was the highest around $10 \mathrm{am}$ in the natural recreation forests in North Chungcheong-Province, while the concentration was the highest at night in the forests in Jeju Island (Lee et al. 2007, Park et al. 2010). Harrison et al. (2001) have reported that the concentration of monoterpenes could be the highest at night because monoterpene-scavenging radicals such as $\mathrm{OH}$ and $\mathrm{O}_{3}$ were reduced at night, despite the fact that monoterpene emissions were the highest during the daytime.

\section{Seasons}

Korea has four distinct seasons, and the physiological properties of trees change depending on the season. Therefore, seasonal temperatures and the amount of daylight, as well as physiology-dependent terpene synthase activities affect the concentration of terpenes in the air (Lee et al. 2011). For example, the concentration of terpenes was the highest from May to August in the green spaces in Seoul metropolis. The 


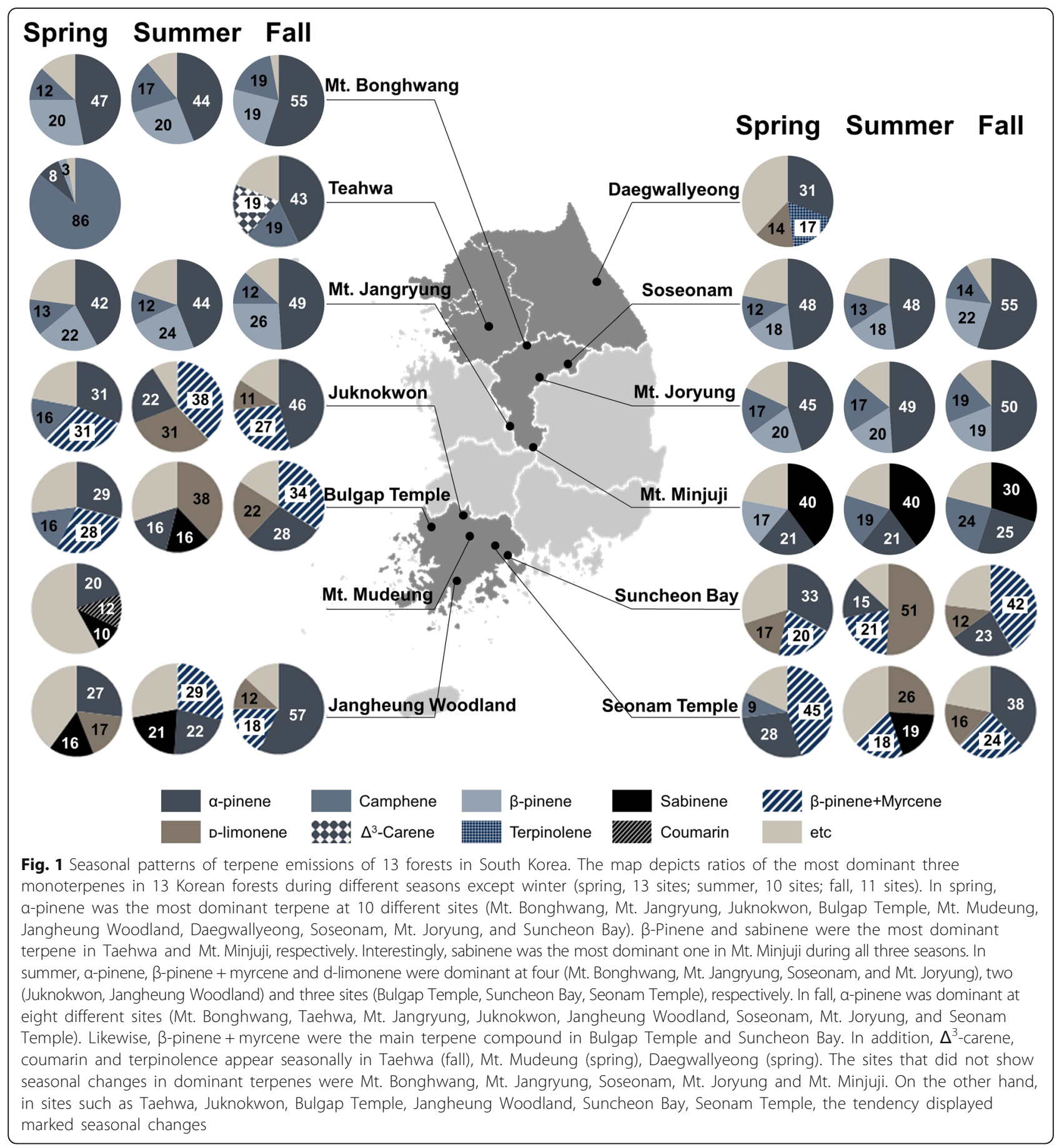

concentration increased in spring, reached its highest level during August and declined thereafter (Lee et al. 2011). A similar pattern was observed in studies at the main trails of Mt. Mudeung in the recreation forest in the North Chungcheong-Province area, Ulsan, and Busan (Byeon et al. 2011, Lee et al. 2012a, Lee et al. 2012b, Lee et al. 2013, Jang and Kim 2015). However, the concentration of terpenes in the air was not consistently correlated with seasonal temperature changes, probably due to rainfall and other factors (Lee et al. 2011). The seasonal variation of the terpene concentration in the air differed depending on the type of terpene; the concentrations were the highest during the summer for $\alpha$-pinene and $\beta$-pinene, during spring for cymene and d-limonene, and during autumn for camphene (Lee et al. 2012a). 


\section{Other factors and limitations}

Aside from the above-mentioned factors, the growing environment of the tree, the relative humidity, the moisture content of the leaf surface, and the wind speed affect the emission rates and concentration of terpenes in the air (Kim et al. 2004, Kang and Kim 2012, Lee et al., 2015b). The emission rates and concentration of terpenes in the air were positively correlated with a good growing environment and negatively correlated with tree age and wind speed (Kim 2001). Indeed, in a Korean pine forest in the Pusan area, the concentration of terpenes was high when the wind speed was low (Kang and Kim 2012, Jang and Kim 2015). The relative humidity was positively correlated with the emission rate of $\alpha$ pinene, while it was negatively correlated with that of camphene (Lee et al., 2015b).

Numerous meteorological and geographical factors can individually affect terpene emissions from forests as described previously, but their effects can be further exacerbated or developed unexpectedly from interactions between those factors. Thus, although data from the terpene studies are currently limited even with a single environmental factor, the effects of those factors on the rates and the compositions of terpene emissions should be interpreted from studies based on multi-factorial designs in the future for better understanding of BVOC emissions from forests.

\section{Conclusions}

Scientific evidence has emerged that forests can improve human health, based on studies on the beneficial effects of plant terpenes on the human body (Cho et al. 2017). It has been shown that terpenes lower stress and blood pressure (Kawakami et al. 2004) as well as promote the activity of natural killer cells that inhibit the activity of cancer cells (Li et al. 2009, Li 2010). However, limited data are available for the characteristics of terpenes emitted in Korean forests. We reviewed the status of the research regarding the diversity of terpene composition in some representative coniferous trees and forests found in South Korea. In addition, factors that affect terpene emissions in Korean forests are summarized.

Plants in the same taxonomic group share many common characteristics compared to plants in other taxonomic groups. Thus, similar emission patterns of BVOCs are expected for trees in the same taxonomic classes. The compositions of monoterpenes emitted from trees examined in this review also displayed similar results in that closely related taxonomic species emitted similar major sets of terpenes. For example, $\alpha$-pinene was the major monoterpene emitted from all of the Pinus species. In addition, Yeon et al. (2015) detected 15 18 types of terpene compounds in all of the essential oils of various trees dominant in South Korea when testing 19 types of terpene compounds, indicating that there were no significant differences in the number of detected terpene compounds between the examined coniferous trees. However, emission rankings of the monoterpenes varied depending on species well as genera of trees, possibly due to their genetic backgrounds.

In addition to the genetic variation of the trees, various atmospheric conditions can affect BVOC emissions (Benjamin and Winer 1998, Harley et al. 1999, Latta et al. 2003). Korea has four distinct seasons and a large temperature difference $\left(-20\right.$ to $\left.35{ }^{\circ} \mathrm{C}\right)$ between summer and winter, which is significant compared to other Asian countries. The examination of monoterpene emissions from various trees in South Korea indicated that the emission rates, as well as the component ratios, were affected by numerous environmental conditions such as the season, temperature, tree age, and region. Since the environmental conditions in Korean forests are highly variable, additional studies on the interrelation between factors affecting terpene emissions in Korean forests are needed.

Terpene emissions from a given species and concentrations of terpenes the species were found to be highly correlated. It has been shown that plants featuring high and low terpene concentrations also possess correspondingly high and low emission rates (Lerdau et al. 1995, Ormeño et al. 2007, Ormeño et al. 2010). In order to achieve beneficial effects on human health via emission of forest aerosols, a plant species with a high terpene emission rate would be advantageous. Since all the species displayed different hourly emission rates in the experiment performed by Kim and Lee (2010), it is suggested that in addition to the terpene composition, the emission rate of a plant should be also considered for the selection of a tree species for forest bathing.

Although terpenes from plants are known to be beneficial for human health, there has been an increased interest in the potential environmental effects of BVOCs on global greenhouse gas and ozone formation (Guenther et al. 1995, Pier 1995, Kesselmeier et al. 2000). Recently, a number of studies in East Asia have been reported regarding the negative roles of BVOCs on regional air quality (Bao et al. 2010). Thus, upon large-scale afforestation, at least two factors should be considered to select a proper plant species, such as enhancement of the quality of the atmospheric environment as well as beneficial effects on human health. Accordingly, the BVOC emission patterns and amounts from various trees in the country should be precisely characterized.

To date, many studies have shown that the chemoprevention effects of forest bathing on people are achieved by inhaling the various phytochemicals produced by trees and that the major components of these phytochemicals are terpenes. While the interest in forest bathing is 
increasing, the data on terpene emission patterns and amounts from various forests in South Korea are currently limited. Thus, in order to propose the best approach to use various terpenes and forests on behalf of the environment as well as human beings in Korea, future studies should be conducted on the terpene production of more forests in various regions of the country and on improving the understanding of the regional characteristics of terpene distribution.

\section{Abbreviations}

BVOC: Biogenic volatile organic compound; VOC: Volatile organic compound

\section{Acknowledgements}

Not applicable.

\section{Funding}

This research was supported by the National Research Foundation of Korea (NRF) funded by the Ministry of Science, ICT and Future Planning (NRF-2016M3C1B6927986).

\section{Availability of data and material}

Not applicable.

\section{Authors' contributions}

$\mathrm{KL}$, JBK, and $\mathrm{YL}$ were involved in drafting the manuscript, and $\mathrm{YJ}$ participated in the acquisition of data. JL, KSC, and ISL made contributions to conception and revision of this manuscript. All authors read and approved the final manuscript.

\section{Competing interests}

The authors declare that they have no competing interests.

\section{Consent for publication}

Not applicable.

Ethics approval and consent to participate

Not applicable.

\section{Publisher's Note}

Springer Nature remains neutral with regard to jurisdictional claims in published maps and institutional affiliations.

Received: 23 February 2017 Accepted: 3 May 2017

Published online: 18 May 2017

\section{References}

Aydin, Y. M., Yaman, B., Koca, H., Dasdemir, O., Kara, M., Altiok, H., Dumanoglu, Y., Bayram, A., Tolunay, D., \& Odabasi, M. (2014). Biogenic volatile organic compound (BVOC) emissions from forested areas in Turkey: Determination of specific emission rates for thirty-one tree species. Science of the Total Environment, 490, 239-253.

Bao, H., Kondo, A., Kaga, A., Tada, M., Sakaguti, K., Inoue, Y., Shimoda, Y., Narumi, D., \& Machimura, T. (2008). Biogenic volatile organic compound emission potential of forests and paddy fields in the Kinki region of Japan. Environmental Research, 106, 156-169.

Bao, H., Shrestha, K. L., Kondo, A., Kaga, A., \& Inoue, Y. (2010). Modeling the influence of biogenic volatile organic compound emissions on ozone concentration during summer season in the Kinki region of Japan. Atmospheric Environment, 44, 421-431.

Benjamin, M. T., \& Winer, A. M. (1998). Estimating the ozone-forming potential of urban trees and shrubs. Atmospheric Environment, 32, 53-68.

Byeon, G., Jeong, S., Kim, S., Yu, B., Park, S., Lee, J., Kim, D., Park, H. (2011) Study on phytoncide occurrence characteristics in Ulsan area following season. Proceedings of the Korean Environmental Sciences Society Conference, 20, 231-232.

Cho, K. S., Lim, Y-R., Lee, K., Lee, J., Lee, J. H., Lee, I-S. (2017) Terpenes from forests and human health. Toxicological Research. In press
Dominguez-Taylor, P., Ruiz-Suarez, L., Rosas-Perez, I., Hernandez-Solis, J., \& Steinbrecher, R. (2007). Monoterpene and isoprene emissions from typical tree species in forests around Mexico City. Atmospheric Environment, 41, 2780-2790.

Dubey, V. S., Bhalla, R., \& Luthra, R. (2003). An overview of the non-mevalonate pathway for terpenoid biosynthesis in plants. Journal of Biosciences, 28, 637 .

Geron, C., Rasmussen, R., Arnts, R. R., \& Guenther, A. (2000). A review and synthesis of monoterpene speciation from forests in the United States. Atmospheric Environment, 34, 1761-1781.

Geron, C., Guenther, A., Greenberg, J., Loescher, H. W., Clark, D., \& Baker, B. (2002). Biogenic volatile organic compound emissions from a lowland tropical wet forest in Costa Rica. Atmospheric Environment, 36, 3793-3802.

Gershenzon, J., \& Dudareva, N. (2007). The function of terpene natural products in the natural world. Nature Chemical Biology, 3, 408-414.

Guenther, A. (1993). Isoprene and monoterpene emission rate variability: model evaluations and sensitivity analyses. Journal of Geophysical Research, 98, 12609-12617.

Guenther, C. (2006). Estimates of global terrestrial isoprene emissions using MEGAN (Model of Emissions of Gases and Aerosols from Nature). Atmospheric Chemistry and Physics, 6, 3181-3210.

Guenther, A. B., Monson, R. K., \& Fall, R. (1991). Isoprene and monoterpene emission rate variability: observations with eucalyptus and emission rate algorithm development. Journal of Geophysical Research. Atmospheres, 96, 10799-10808.

Guenther, A., Hewitt, C. N., Erickson, D., Fall, R., Geron, C., Graedel, T., Harley, P., Klinger, L., Lerdau, M., \& McKay, W. (1995). A global model of natural volatile organic compound emissions. Journal of Geophysical Research. Atmospheres, 100, 8873-8892.

Guenther, A., Otter, L., Zimmerman, P., Greenberg, J., Scholes, R., \& Scholes, M. (1996). Biogenic hydrocarbon emissions from southern African savannas. Journal of Geophysical Research. Atmospheres, 101, 25859-25865.

Hakola, H., Laurila, T., Rinne, J., \& Puhto, K. (2000). The ambient concentrations of biogenic hydrocarbons at a northern European, boreal site. Atmospheric Environment, 34, 4971-4982.

Hakola, H., Tarvainen, V., Laurila, T., Hiltunen, V., Hellén, H., \& Keronen, P. (2003). Seasonal variation of VOC concentrations above a boreal coniferous forest. Atmospheric Environment, 37, 1623-1634.

Harley, P. C., Monson, R. K., \& Lerdau, M. T. (1999). Ecological and evolutionary aspects of isoprene emission from plants. Oecologia, 118, 109-123.

Harrison, D., Hunter, M., Lewis, A., Seakins, P., Nunes, T., \& Pio, C. (2001). Isoprene and monoterpene emission from the coniferous species Abies Borisiiregis-implications for regional air chemistry in Greece. Atmospheric Environment, 35, 4687-4698.

Holm, Y., \& Hiltunen, R. (1997). Variation and inheritance of monoterpenes in Larix species. Flavour and Fragrance Journal, 12, 335-339.

Jang, E., \& Kim, D. (2015). Study on concentration distribution characteristics of terpenes in Galmaetkkil of Busan area in the region, season, and time. The Annual Report of Busan Metropolitan City Institute of Health \& Environment, 25, 375-376.

Janson, R. W. (1993). Monoterpene emissions from Scots pine and Norwegian spruce. Journal of Geophysical Research: Stmospheres, 98 , 2839-2850.

Ji, D., Kim, S., \& Han, J. (2002). A study on the comparison to source profile of the major terpenes from pine tree and Korean pine tree. Journal of Korean Society for Atmospheric Environment, 18, 515-525.

Jo, G. G., \& Kim, J. H. (2010). Changes in terpenes of three kinds of pine needles during litter decomposition. Journal of Ecology and Environment, 33, 175-186.

Kang, D., \& Kim, K. (2012). Effects of temperature and wind velocity on phytoncide concentration in Korean pine (Pinus Koraiensis) forest. Journal of Korean Society for Plants, People and Environment, 15, 15-20.

Kawakami, K., Kawamoto, M., Nomura, M., Otani, H., Nabika, T., \& Gonda, T. (2004). Effects of phytoncides on blood pressure under restraint stress in SHRSP. Clinical and Experimental Pharmacology and Physiology, 31, S27-S28.

Kesselmeier, J., Kuhn, U., Wolf, A., Andreae, M., Ciccioli, P., Brancaleoni, E., Frattoni, M., Guenther, A., Greenberg, J., \& Vasconcellos, P. D. C. (2000). Atmospheric volatile organic compounds (VOC) at a remote tropical forest site in central Amazonia. Atmospheric Environment, 34, 4063-4072.

Kim, J.-C. (2001). Factors controlling natural VOC emissions in a southeastern US pine forest. Atmospheric Environment, 35, 3279-3292.

Kim, D-H. (2016). Chapter 35. Republic of South Korea. In IA Claude Vidal, L Hernández, JJ Redmond (Eds.), National Forest Inventories: Assessment of 
Wood Availability and Use (pp. 655-665) Springer International Publishing Switzerland.

Kim, H.-C., \& Lee, K.-H. (2010). A study on emission rates of VOCs from conifers at Jeju Island. Journal of Environmental Science International, 19, 627-637.

Kim, B. Y., \& Lee, C.-T. (2015). Production of phytoncide from Korean pine cone waste by steam distillation. Applied Chemistry for Engineering, 26, 648-658.

Kim, J.-C., J-h, H., Gang, C.-H., Sunwoo, Y., Kim, K.-J., \& Lim, J.-H. (2004). Comparison of monoterpene emission rates from conifers. Journal of Korean Society for Atmospheric Environment, 20, 175-183.

Kim, J.-C., Kim, K.-J., Kim, D.-S., \& Han, J.-S. (2005). Seasonal variations of monoterpene emissions from coniferous trees of different ages in Korea. Chemosphere, 59, 1685-1696.

Kim, K-J., Kim, J-C., Lim, J-H., SunWoo, Y., Park, H-J., Cho, K-T. (2007a) Study on natural VOC emission rates and characteristics emitted from Larix Leptoleis (Sieb. et Zucc.) Gordon. Journal of Environmental Science International, 16, 151-158.

Kim, K-J., Kim, J-C., Lim, Y-J., Son, Y-S., SunWoo, Y., Cho, K-T. (2007b) A Study on the isoprene emissioin rates from deciduous tree (Quercus Mongolica Fischer). Journal of Environmental Science International, 16, 269-275.

Kim, H-C., Oh, S. S., Song, Y. C., Kim, Y. J. (2013a) Distribution characteristics of phytoncide in Jeolmul Natural Recreation Forest of Jeju. Journal of Naturopathy, 2, 89-98.

Kim, H-C., Oh, S. S., Song, Y. C., Kim, Y. J. (2013b) Distribution characteristics of phytoncide in Seogwipo Natural Recreation Forest. Journal of Naturopathy, 2, 99-107.

Kim, S-Y., Jiang, X., Lee, M., Turnipseed, A., Guenther, A., Kim, J-C., Lee, S-J., Kim, S. (2013c) Impact of biogenic volatile organic compounds on ozone production at the Taehwa Research Forest near Seoul, South Korea. Atmospheric environment 70: 447-453.

Kim, G., Kwon, C., Yeom, D., Joung, D., Choi, Y. H., \& Park, B.-J. (2014). Relationship between NVOCs concentration and Korean red pine (Pinus densiflora S. et Z.) forest environment in spring season. Journal of Korean Forest Society, 103, 483-489.

Kirby, J., \& Keasling, J. D. (2009). Biosynthesis of plant isoprenoids: perspectives for microbial engineering. Annual Review of Plant Biology, 60, 335-355.

Klinger, L., Greenburg, J., Guenther, A., Tyndall, G., Zimmerman, P., M'bangui, M., Moutsamboté, J. M., \& Kenfack, D. (1998). Patterns in volatile organic compound emissions along a savanna-rainforest gradient in central Africa. Journal of Geophysical Research. Atmospheres, 103, 1443-1454.

Klinger, L., Li, Q. J., Guenther, A., Greenberg, J., Baker, B., Bai, J. H. (2002). Assessment of volatile organic compound emissions from ecosystems of China. Journal of Geophysical Research: Atmospheres, 107. ACH 16-1-ACH 16-21.

Kong, W. (1999). The vertical distribution of air temperature and thermal amplitude of alpine plants on Mt. Halla, Cheju Island. Korea Journal Korean Geographical Society, 34, 385-393.

Korea Forest Service. (2016). Basic statistics of forest. Statistical Yearbook of Forest, 2016, 14.

Korean Statistical Information. (2015) http://kosis.kr/statisticsList/statisticsList 01List.jsp?vwcd=MT_ZTITLE\&parentld=F\#SubCont. Accessed 20 Feb 2017.

Kurose, K., Okamura, D., \& Yatagai, M. (2007). Composition of the essential oils from the leaves of nine Pinus species and the cones of three of Pinus species. Flavour and Fragrance Journal, 22, 10-20.

Kwak, J., Lee, K., Han, B., Song, J., \& Jang, J. (2013). A study on the vegetation structure of evergreen broad-leaved forest Dongbaekdongsan (Mt.) in Jejudo, Korea. Korean Journal of Environment and Ecology, 27, 241-252.

Lange, B. M., \& Ahkami, A. (2013). Metabolic engineering of plant monoterpenes, sesquiterpenes and diterpenes-current status and future opportunities. Plant Biotechnology Journal, 11, 169-196.

Latta, R. G., Linhart, Y. B., Snyder, M. A., \& Lundquist, L. (2003). Patterns of variation and correlation in the monoterpene composition of xylem oleoresin within populations of ponderosa pine. Biochemical Systematics and Ecology, 31, 451-465.

Lee, C. (1982). Illustrated flora of Korea, Hyangmunsa.

Lee, D. (2002). Ecology of Korea. In The 8th Intecol International Congress of Ecology (pp. 19-46).

Lee, G. H., Kim, H. C., Lee, H. Y., \& Heo, C.-G. (2007). Concentrations of monoterpenes in the atmosphere of forests at Jeju area. Korean Society for Atmospheric Environment, 5, 1681-1684.

Lee, J. S., Bae, I. S., Kim, H. S., Lee, W. Y., NO YK, Yoon, J. S., Jung, K., Eom, S. W., Chae, Y. Z. (2011) Properties of phytoncide concentration at the green spaces in the Seoul Metropolis. Report of S.I.H.E, 47, 130-139.

Lee, D-H., Kim, M-H., Seo, H-J., Min, G-W., Kim, S-H., Seo, K-Y., Jeong, W-S., Kang, Y-J., An, K-W., Paik, G-J. (2012a) Correlation analysis between terpene and meteorological factors at artificial coniferous forest of Mt. Moodeung. Journal of Environmental Science International, 21, 1221-1234.

Lee, S-W., Park, D. G., Kim, K-Y. (2012b) Characteristics of phytoncide production at the recreation forest in the Chungbuk area. Journal of Environmental Impact Assessment, 21, 279-287.

Lee, D.-H., Kim, M.-H., Park, O.-H., Park, K.-S., An, S.-S., Seo, H.-J., Jin, S.-H., Jeong W.-S., Kang, Y.-J., \& An, K.-W. (2013). A Study on the distribution characteristics of terpene at the main trails of Mt. Mudeung. Korean Journal of Environmental Health Sciences, 39, 211-222.

Lee, D-H., Park, K-A., Lee, S-H., Song, H-M., Lee, K-W., Jeong, H-Y., Seo, G-Y., Cho, Y-G., Kim, E-S. (2015a) Distribution characteristics on volatile organic compounds at the forest of Mt. Mudeung and downtown. Analytical Science and Technology, 28, 246-254.

Lee, K-H., Kim, H-C., Hu, C-G. (2015b) A Study on the Estimation of BVOCs Emission in Jeju Island (2): Emission Characteristic and Situation. Journal of Environmental Science International, 24, 207-219.

Lerdau, M., Matson, P., Fall, R., \& Monson, R. (1995). Ecological controls over monoterpene emissions from Douglas-fir (Pseudotsuga menziesii). Ecology, $76,2640-2647$

Li, Q. (2010). Effect of forest bathing trips on human immune function. Environmental Health and Preventive Medicine, 15, 9-17.

Li, Q., Kobayashi, M., Wakayama, Y., Inagaki, H., Katsumata, M., Hirata, Y., Hirata, K., Shimizu, T., Kawada, T., \& Park, B. (2009). Effect of phytoncide from trees on human natural killer cell function. International Journal of Immunopathology and Pharmacology, 22, 951-959.

Lim, J.-H., Kim, J.-C., Kim, K.-J., Son, Y.-S., Sunwoo, Y., \& Han, J.-S. (2008). Seasonal variations of monoterpene emissions from Pinus densiflora in East Asia. Chemosphere, 73, 470-478.

Martin, D. M., Gershenzon, J., \& Bohlmann, J. (2003). Induction of volatile terpene biosynthesis and diurnal emission by methyl jasmonate in foliage of Norway spruce. Plant Physiology, 132, 1586-1599.

Mewalal, R., Rai, D. K., Kainer, D., Chen, F., Külheim, C., Peter, G. F., \& Tuskan, G. A. (2017). Plant-derived terpenes: A feedstock for specialty biofuels. Trends in Biotechnology, 35, 227-240.

Monson, R. K., Lerdau, M. T., Sharkey, T. D., Schimel, D. S., \& Fall, R. (1995). Biological aspects of constructing volatile organic compound emission inventories. Atmospheric Environment, 29, 2989-3002.

Oh, K. K. (1994). Plant community structure of evergreen broadleaved forest in Mt. Turyunsan. Korea. Journal of Korean Applied Ecology, 8, 43-57.

Oh, G.-Y., Seo, Y.-G., Park, G.-H., Kim, I.-S., Bae, J.-S., Park, H.-Y., Yang, S.-I., Jeon, J.-M., Jeong, M.H., \& Seo, Y.-S. (2012). The characteristics of monoterpene and air quality in ambient air at forested road in Jeollanam-do. Journal of Korean Forest Society, 101, 195-202.

Ormeño, E., Fernandez, C., \& Mévy, J.-P. (2007). Plant coexistence alters terpene emission and content of Mediterranean species. Phytochemistry, 68, 840-852.

Ormeño, E., Gentner, D. R., Fares, S., Karlik, J., Park, J. H., \& Goldstein, A. H. (2010). Sesquiterpenoid emissions from agricultural crops: correlations to monoterpenoid emissions and leaf terpene content. Environmental Science \& Technology, 44, 3758-3764.

Padhy, P., \& Varshney, C. (2005). Emission of volatile organic compounds (VOC) from tropical plant species in India. Chemosphere, 59, 1643-1653.

Park, D., Shin, P., Kim, C., Kweon, O., \& Suk, T. (2010). Distribution characteristics of phytoncide (monoterpene) in the recreation forest in Chungchenbukdo. The Annual Report of Chungchenbuk-do Institute of Health \& Environment, 19, 87-115.

Peñuelas, J., \& Staudt, M. (2010). BVOCs and global change. Trends in Plant Science, 15, 133-144.

Pichersky, E., Noel, J. P., \& Dudareva, N. (2006). Biosynthesis of plant volatiles: nature's diversity and ingenuity. Science, 311, 808-811.

Pier, P. A. (1995). Isoprene emission rates from northern red oak using a whole-tree chamber. Atmospheric Environment, 29, 1347-1353.

Pokorska, O., Dewulf, J., Amelynck, C., Schoon, N., Joó, É., Šimpraga, M., Bloemen, J., Steppe, K., \& Van Langenhove, H. (2012). Emissions of biogenic volatile organic compounds from Fraxinus excelsior and Quercus robur under ambient conditions in Flanders (Belgium). International Journal of Environmental Analytical Chemistry, 92, 1729-1741.

Sabillón, D., \& Cremades, L. V. (2001). Diurnal and seasonal variation of monoterpene emission rates for two typical Mediterranean species (Pinus pinea and Quercus ilex) from field measurements — relationship with temperature and PAR. Atmospheric Environment, 35, 4419-4431.

Sindelarova, K., Granier, C., Bouarar, I., Guenther, A., Tilmes, S., Stavrakou, T., Müller, J.-F., Kuhn, U., Stefani, P., \& Knorr, W. (2014). Global data set of biogenic VOC emissions 
calculated by the MEGAN model over the last 30 years. Atmospheric Chemistry and Physics, 14, 9317-9341.

Son, Y.-S., Hwang, Y.-S., Sung, J.-H., \& Kim, J.-C. (2012). Variations of BVOCs emission characteristics according to increasing PAR. Journal of Korean Society for Atmospheric Environment, 28, 77-85.

Son, Y.-S., Kim, K.-J., Jung, I.-H., Lee, S.-J., \& Kim, J.-C. (2015). Seasonal variations and emission fluxes of monoterpene emitted from coniferous trees in East Asia: focused on Pinus rigida and Pinus koraiensis. Journal of Atmospheric Chemistry, 72, 27-41.

Staudt, M., \& Seufert, G. (1995). Light-dependent emission of monoterpenes by holm oak (Quercus ilex L.). Naturwissenschaften, 82, 89-92.

The Plant List Version 1.1. http://www.theplantlist.org/tpl1.1/search?q=pinus. Accessed 20 Feb 2017.

Tollsten, L., \& Müller, P. M. (1996). Volatile organic compounds emitted from beech leaves. Phytochemistry, 43, 759-762.

Warneck, P. (1988). Chemistry of the natural atmosphere. In International geophysics series, Elsvier (Vol. 41, pp. 223-237).

Xiaoshan, Z., Yujing, M., Wenzhi, S., \& Yahui, Z. (2000). Seasonal variations of isoprene emissions from deciduous trees. Atmospheric Environment, 34, 3027-3032.

Xiaoyu, S., Jing, W., Xin, Y., \& Weiqiang, C. (2006). Analysis of volatile oil constituents in pinecone of Pinus koraiensis by gas chromatography-mass spectrometry. Chinese Journal of Analytical Chemistry, 34, S217-S219.

Yeon, P. S., Lee, H. E., \& Shin, C. S. (2015). Assay of terpene compounds contained in the tree for forest healing. Journal of Korean Society for People Plants and Environment Vol, 18, 333-339.

Yokouchi, Y., \& Ambe, Y. (1984). Factors affecting the emission of monoterpenes from red pine (Pinus densiflora). Plant Physiology, 75, 1009-1012.

Yu, E. J., Kim, T. H., Kim, K. H., \& Lee, H. J. (2004). Aroma-active compounds of Pinus densiflora (red pine) needles. Flavour and Fragrance Journal, 19, 532-537.

Yun, C.-W., Kim, H.-J., Lee, B.-C., Shin, J.-H., Yang, H. M., \& Lim, J. H. (2011). Characteristic community type classification of forest vegetation in South Korea. Journal of Korean Forest Society, 100, 504-521.

Zimmerman, P. R. (1979) Testing of hydrocarbon emissions from vegetation, leaf litter and aquatic surfaces, and development of a methodology for compiling biogenic emission inventories. USA: US Environmental Protection Agency EPA-450/4-79-004.

Zulak, K. G., \& Bohlmann, J. (2010). Terpenoid biosynthesis and specialized vascular cells of conifer defense. Journal of Integrative Plant Biology, 52, 86-97.

\section{Submit your next manuscript to BioMed Central and we will help you at every step:}

- We accept pre-submission inquiries

- Our selector tool helps you to find the most relevant journal

- We provide round the clock customer support

- Convenient online submission

- Thorough peer review

- Inclusion in PubMed and all major indexing services

- Maximum visibility for your research

Submit your manuscript at www.biomedcentral.com/submit

) Biomed Central 